\title{
OPTIMALISASI PERAN PEMBIMBING KEMASYARAKATAN DALAM PENCEGAHAN RESIKO RESIDIVIS TERHADAP KLIEN PEMASYARAKATAN (STUDI KASUS DI BALAI PEMASYARAKATAN KELAS II PEKANBARU)
}

\author{
Risky Rohmat Ramadhan \\ Politeknik Ilmu Pemasyarakatan Depok, Depok, Indonesia \\ \{riskyrohmat96@gmail.com\}
}

\begin{abstract}
Abstrak
Peran Pembimbing Kemasyarakatan dalam upaya pencegahan resiko residivis masih belum berjalan secara optimal. hal ini dikarenakan masih adanya beberapa hambatan yang dialami oleh petugas Pembimbing Kemasyarakatan baik itu dari segi pemberian program bimbingan maupun pengawasan yang dilakukan terhadap klien. Penelitian ini bertujuan untuk memberikan penjelasan tentang tugas Pembimbing Kemasyarakatan beserta faktor-faktor yang menjadi penyebab terjadinya pengulangan tindak pidana atau residivis yang dilakukan oleh klien Pemasyarakatan. dari hasil pembahasannya masih perlu adanya penguatan terhadap tugas Pembimbing Kemasyarakatan dan kerja sama baik itu dengan keluarga pelaku sampai aparat penegak hukum disekitar lingkungan pelaku. Jadi kesimpulannya adalah Pembimbing Kemasyarakatan harus melaksanakan program bimbingan yang sesuai dengan kemampuan yang dimiliki oleh klien dan juga melakukan kerja sama terhadap berbagai pihak sebagai bentuk pengawasan terhadap klien agar tidak menjadi seorang residivis.
\end{abstract}

\section{Kata Kunci: Optimalisasi, Residivis, Pembimbing Kemasyarakatan.}

\begin{abstract}
The role of Community Guidance in efforts to prevent recidivist risk is still not running optimally. This is because there are still several obstacles experienced by Community Guidance officers, both in terms of providing guidance and supervision programs carried out on clients. This study aims to provide an explanation of the duties of the Community Guidance and the factors that cause the occurrence of criminal or recidivist acts committed by Correctional clients. From the results of the discussion, there is still a need for strengthening of the task of Community Guidance and cooperation, both with the perpetrator's family to law enforcement officials around the perpetrator's environment. So the conclusion is that the Community Counselor must carry out a guidance program in accordance with the abilities possessed by the client and also collaborate with various parties as a form of supervision of the client so that he does not become a recidivist
\end{abstract}

Keywords: Optimization, Recidivist, Community Advisor.

\section{Latar Belakang}

Seperti yang kita ketahui bersama dalam Undang-Undang Dasar 1945 telah dijelaskan bahwa, Indonesia merupakan Negara yang berlandaskan atas hukum dan tidak berdasarkan atas sebuah kekuasaan saja. Indonesia

merupakan Negara yang diatur oleh Pancasila dan juga UndangUndang Dasar 1945. Dimana hukum mengatur tentang segala baik atau 
buruknya perilaku seseorang memberikan sanksi sebagai bentuk perubahan terhadap perilaku diri manusia. Sebuah kejahatan merupakan sebuah fenomena yang terjadi disekitar masyarakat karena tidak terlepas dari setiap kehidupan sehari-hari. Kejahatan mengandung banyak artian merupakan suatu pengertian dan penamaan yang relatif dan mengandung variabilitas dan dinamis yang saling berhubungan apakah itu baik atau buruk, yang di nilai sebagian besar orang sebagai perbuatan anti sosial terhadap sebuah penilaian sosial dan waktu. Kejahatan itu sendiri dapat dilakukan oleh siapa saja, dimana saja, dan kapan saja tanpa adanya sebuah bentuk rencana. Ketika adanya sebuah kesempatan baik itu sekecil apapun seseorang bisa melakukan sebuah tindak kejahatan, dimana kejahatan ini pastinya dapat merugikan orang lain, keluarga dan diri sendiri. Sebut saja sebuah kejahatan yang dilakukan seperti tindak pidana pencurian, seseorang yang melakukan sebuah pencurian biasanya tergolong dikarenakan faktor ekonomi dan ada juga karena rasa penasaran atau hanya ingin ikutan saja. Tindak pidana pencurian di Indonesia sendiri sangat kerap terjadi disetiap wilayah baik itu wilayah pedesaan hingaa wilayah perkotaan Dimana pelaku tindak pidana pencurian tersebut harus diproses sesuai dengan hukum yang berlaku berdasarkan pasal-pasal yang telah diatur dalam Kitab Undang-Undang Hukum Pidana (KUHP). Setelah melalu serangkaian proses hukum mulai dari proses penyidikan sampai pada akhirnya proses persidangan dan mendapat putusan oleh hakim yang selanjutnya akan menjalani masa pidana di Lembaga Pemasyarakatan (LAPAS) dan statusnya berubah menjadi Narapidana. Lembaga Pemasyarakatan menurut UndangUndang No 12 Tahun 1995 tentang pemasyarakatan merupakan tempat untuk pelaksanaan proses pembinaan Narapidana dan Anak Didik Pemasyarakatan, yang selanjutnya Narapidana menurut pasal 1 ayat 7 Undang-Undang No 12 Tahun 1995 tentang Pemasyarakatan seorang terpidana yang menjalani masa pidana hilang kemerdekaan di Lembaga Pemasyarakatan.

Bagaimanapun juga Narapidana adalah manusia biasa yang memiliki potensi yang dapat dilatih dan dikembangkan untuk menjadi manusia yang produktif, dan bisa menjadi lebih baik daripada sebelumnya. Semakin banyak dan beragam segala perilaku tindak pidana yang ada di Indonesia, menjadikan peran dari Lembaga Pemasyarakatan sangat penting dalam menjunjang perubahan dari narapidana itu sendiri. Baik dari setiap program pembinaan yang diberikan terhadap narapidana dan juga pelatihan yang diberikan. Setelah menjalani masa pembinaan nantinya narapidana yang bebas akan melaksanakan bimbingan yang dilaksanakan oleh pihak Bapas, Bapas menurut Undang-Undang No 12 Tahun 1995 tentang Pemasyarakatan merupakan sebuah pranata dalam pelaksanaan bimbingan kemasyrakatan. Adapun dalam bapas sendiri terdapat petugas yaitu Pembimbing Kemasyarakatan dimana tugas Pembimbing Kemasyarakatan tercantum dalam pasal 2 ayat 1 Keputusan Menteri Kehakiman RI No. M.01-PK.10 Tahun 1998 salah satunya adalah bimbingan kerja bagi klien pemasyarakatan.

Namun dalam kenyataannya masih terdapat Narapidana yang melakukan pengulangan tindak pidana baik itu tindak pidana yang sama maupun tindak pidana lainnya. Pengulangan tindak pidana ini bisa disebabkan oleh faktor masih kurangnya pembinaan dan bimbingan yang diberikan oleh petugas 
Pemasyarakatan. Sesuai dalam peraturan Pemerintah Nomor 31 tahun 1999 tentang Pembinaan dan Pembimbingan pasal 4 ayat 1 menyatakan : pelaksanaan pembinaan dan pembimbingan Warga Binaan Pemasyarakatan dilakukan oleh petugas Pemasyarakatan yang terdiri atas Pembina Pemasyarakatan dan Pembimbing Kemasyarakatan. Pembimbingan terhadap klien dilakukan oleh Pembimbing Kemasyarakatan di Bapas.

Pembimbing Kemasyarakatan ditetapkan sebagai Pejabat Fungsional Penegak Hukum sebagaimana tertuang dalam pasal 8 Undang-Undang No 12 Tahun 1995 tentang Pemasyarakatan. Maka Pembimbing Kemasyarakatan wajib melaksanakan bimbingan terhadap klien dalam hal ini dilakukan bimbingan keterampilan, bimbingan konseling agar mempunyai bekal untuk menunjang hidupnya setelah menjalani masa pidana. Harus disadari adanya perubahan sistem kepenjaraan menjadi sistem Pemasyarakatan memerlukan proses yang sangat panjang yaitu dengan adanya penyempurnaanpenyempurnaan di semua bidang baik dalam bidang administrasi, teknis maupun sarana dan prasarana yang mendukung terlaksananya proses perubahan sistem tersebut.

Sebagai petugas teknis pelaksanaan Pembimbingan Klien yang dilakukan oleh Bapas adalah Pembimbing Kemasyarakatan merupakan orang yang harus memiliki keahlian dan keterampilan teknis dalam bidang kesejahteraan sosial, sehingga dapat membantu klien yang sedang mengalami permasalahan dengan fungsi sosialnya, selain itu seorang pembimbing kemasyarakatan harus menguasai metode dan teknik pembimbingan serta kemampuan yang professional. Menurut pengamatan penulis yang terjadi di BAPAS Kelas II
Pekanbaru terlihat bahwa dalam kenyataannya peran petugas Pembimbing Kemasyarakatan masih kurang optimal dalam pelaksanaan program bimbingan yang diberikan dikarenakan terkendala oleh kondisi Pandemi Corona Saat ini, dimana program bimbingan yang diberikan hanya bisa dilaksanakan melalui via Daring atau melalui online dan masih kurangnya bentuk pengawasan terhadap klien Pemasyarakatan karena jarak yang cukup jauh.

Berdasarkan uraian tersebut diatas maka penulis ingin mengetahui peran Pembimbing Kemasyarakatan dalam mencegah resiko residivis yang dilakukan oleh klien Pemasyarakatan dan mengoptimalkan tugas dan fungsi Pembimbing Kemasyarakatan itu sendiri maka penulis mengambil judul "Optimalisasi Peran Pembimbing Kemasyarakatan Dalam Mencegah Resiko Residivis Terhadap Klien Pemasyarakatan di Balai Pemasyarakatan Kelas II Pekanbaru',

\section{Metode}

Metode penelitian yang digunakan dalam penelitian ini adalah metode penelitian Kualitatif dengan pendekatan Deskriptif. Metode penelitian Kualitatif merupakan metode penelitian yang berlandaskan pada filsafat postpositivisme atau enterpretetif, digunakan untuk mengetahui setiap kondisi obyek secara nyata dan alamiah, dimana peneliti merupakan instrument kunci dan hasil dari penelitian bersifat makna, memahami setiap kondisi dari data yang diteliti dan menemukan hipotesis (Sugiyono 2017:9).

Metode penelitian Deskriptif sendiri merupakan metode dimana seorang peneliti mengumpulkan data, menganalisis data tersebut secara kritis dan menyimpulkannya berdasarkan 
fakta-fakta pada saat penelitian berlangsung. Dimana motde ini bertujuan untuk memberikan gambaran serta mendeskripsikan berbagai fakta dan fenomena yang ditemukan dan mengaitkannya satu dengan lainnya. Menurut Bogdan dan Taylor (Moleong, 1975: 5) mendefinisikan pendekatan penelitian deskriptif berupa kata-kata tertulis atau lisan dari orang dan perilaku yang dapat diamati. Oleh karena itu penelitian ini dilakukan dengan cara mengikuti aktivitas yang dilakukan oleh Pembimbing Kemasyarakatan serta beberapa pihak yang terkait. Penelitian ini berfokus pada peranan Pembimbing Kemasyarakatan dalam mencegah resiko residivis di Balai Pemasyarakatan Kelas II Pekanbaru

\section{Pembahasan}

dalam Undang-Undang No 11 Tahun 2012 tentang Sistem Peradilan Pidana Anak pasal 1, Pembimbing Kemasyarakatan adalah pejabat fungsional penegak hukum yang melaksanakan penelitian kemasyarakatan, pembimbingan, pengawasan, pendampingan di dalam dan diluar proses peradilan pidana. Dengan demikian pelaksanaan bimbingan terhadap klien maka pembimbing kemasyarakatan memiliki peran yang sangat penting dalam mengoptimalkan bimbingan terhadap klien dewasa guna mewujudkan tujuan dari sistem pemasyarakatan yang berusaha mengoptimalkan reintegrasi dan tidak terjadinya pengulangan tindak pidana. Dalam hal ini dijelaskan terdapat 7 peran yang harus dimiliki oleh seorang Pembimbing Kemasyarakatan: 1.) Broker yaitu menyediakan pelayanan sosial kepada klien pemasyarakatan, dimana para Pembimbing Kemasyarakatan melaksanakan kerja sama dengan instansi lain untuk mempermudah dalam proses bimbingan yang akan di lakukan oleh klien sesuai dengan masalah yang dihadapinya, namun pada Bapas Kelas II Pekanbaru keterbatasan kerjasama dan kordinasi dengan instansi atau lembaga lain dalam pelaksanaan bimbingan terbatas dikarenakan kondisi pandemic saat ini dan hanya melakukan bentuk kerjasama dengan pihak BNN dalam sosialisasi dan memberikan program bimbingan kemandirian terhadap klien, dimana dalam hal ini harusnya program ini dilaksanakan dalam sebulan sekali namun pada kenyataanya masih sangat jarang dilaksanakan bahkan dalam 1 tahun dilaksanakan 2 kali dalam setahun, 2.) Mediator Yaitu menghubungkan klien dengan berbagai sumber pelayanan sosial yang ada dalam masyarakat, Pembimbing Kemasyarakatan pada Bapas Kelas II Pekanbaru kurang mampu dalam melaksanakan kordinasi dengan klien maupun lembaga sosial lainnya, disebabkan kurangnya kemauan klien dalam mengembangkan dirinya, 3.) Public Educator yaitu memberikan dan menyebarkan informasi mengenasi masalah-masalah dan pelayanan sosial yang tersedia penyampaian informasi mengenai pelayanan sosial kurang efektif karena jangkuan luas, meskipun sistem informasi sudah canggih namun masih ada para klien dengan kondisi pendidikan kalangan dibawah rata-rata maka informasi tersebut tidak sampai terhadap klien, 4.) Advocat yaitu sebagai pembela klien dalam memperjuangkan hak-hak nya memperoleh pelayanan klien agar lembaga menjadi lebih responsive memenuhi kebutuhan klien adapun hak-hak sebagian klien salah satunya yaitu mendapatkan pembinaan di luar lembaga telah terpenuhi tetapi ada juga yang harus diperhatikan yaitu selain memiliki hak klien juga mempunyai 
kewajiban salah satunya yaitu mematuhi semua peraturan dan ketentuan yang berlaku dalam proses pembimbingan, dalam hal ini klien terkadang jarang datang pada saat pelaksanaan laporan karena kurangnya biaya transportasi untuk hadir di Bapas Kelas II Pekanbaru sesuai yang dijadwalkan dalam bimbingan klien tersebut, 5.) Behavior Specialist adalah menjadi ahli yang dapat melakukan berbagai strategi dan teknik pengubahan perilaku, perlu diketahui ahli bisa juga diartikan mahir, padahal pembimbing kemasyarakatan di Bapas Kelas II Pekanbaru peran ini kurang optimal dalam bimbingan dikarenakan pengembangan kemampuan yang terbatas, 6.) Konsultan yaitu memberi nasehat dan saran profesional kepada klien mengenai berbagai cara pemenuhan kebutuhan dan pemecahan masalah, 7.) Konselor yaitu memberikan pelayanan penyelesaian masalah, pembimbing kemasyarakatan harus mampu memecahkan masalah klien dengan tepat dan tidak mengurangi dari azas-azas dalam bimbingan (Rahmat, 2018) salah satunya yaitu kerahasiaan.

Pembimbing kemasyarakatan dalam melaksanakan bimbingan secara optimal maka dibutuhkan tekad, prinsip dan kode etik agar dalam pelaksanaanya dapat berjalan sistematis dan terpadu, adapun prinsip-prinsip dalam bimbingan (Santoso Darwis, 2017) sebagai berikut: a. Prinsip-Prinsip Bimbingan: 1) Bimbingan itu selalu berhubungan dengan sikap dan perilaku WBP, jadi dari beberapa jenis kasus yang dialami oleh klien maka diperlukan bimbingan yang tepat, yang mengikuti azas keterbukaan dimana pembimbing dan klien harus saling terbuka guna penentuan bimbingan sehingga dapat dipecahkan suatu masalah yang dihadapi klien, 2) Dalam proses bimbingan perlu dikenal dan dipahami oleh pembimbing tentang perbedaan individu WBP, agar dalam memberi bimbingan dapat mengenai sasaran dan kebutuhan individu yang dibimbing (individualization), 3) Bimbingan yang diberikan dengan maksud agar WBP yang dibimbing mampu membantu dan menuntun dirinya sendiri dalam menghadapi permasalahan hidup dan kehidupannya seoptimal mungkin (self direction \& to help people to help them selfes), 4) Bimbingan itu diberikan harus terpusat pada permasalahan individu yang dibimbing, bukan terpusat pada permsalahan individu yang membimbing (client centered), 5) Jika permasalahan klien tidak dapat diselesaikan oleh pembimbing, maka perlu adanya kerjasama dengan ahli lain atau lembaga lain yang lebih berkompeten menangani permasalahan tersebut, 6) Dalam proses bimbingan perlu ada upaya pendahuluan dalam mengidentifikasi permasalahan dan kebutuhan invidu yang dibimbing, untuk mempermudah pemahaman dan penerimaan diri individu yang dibimbing. Sehingga dalam pengarahan dan perwujudan sesuai dan tepat pada sasaran, 7) Bimbingan itu harus bersifat fleksibel sesuai dengan kebutuhan individu yang dibimbing dan kebutuhan masyarakat yang serba beragam, 8) Pembimbing harus memiliki kualifikasi kepribadian, pendidikan, pengalaman, kematangan dan kemampuan yang diharapkan oleh individu yang dibimbing dan masyarakat, 9) Pembimbing harus patuh pada kode etik pembimbingan, antara lain khususnya untuk pembimbing orang dewasa misalnya: hormat, pandangan positif, menjaga kerahasian informasi data-data individu yang dibimbing, 10) Individu yang dibimbing (karena orang dewasa) harus diberikan kebebasan dan penghormatan dalam mengungkap 
dirinya. Disini pembimbing hanya bersikap sebagai fasilitator dalam proses bimbingan $b$. Kode Etik dan Keterampilan Dasar Pembimbing Kemasyarakatan Dalam pelaksanaan bimbingan agar tidak menyimpang dari apa yang dilaksanakannya serta berlaku secara profesional maka penulis uraikan kode etik sebagai pembimbing kemasyarakatan yaitu:

1) Pegang teguh rahasia klien dan rahasia-rahasia lain yang berkaitan dengan klienmu hal ini berdasarkan azas kerahasiaan (the principle of confidenciality).

2) Hormati klien karena ia punya harga diri, ia adalah pribadi berbeda dengan pribadi lainnya, agar dalam tahap bimbingan berjalan dengan lancar.

3) Terimalah/ layani klien sebagaimana keberadaannya.

4) Ikut sertakan klien dalam memecahkan masalah (doing with).

5) Tempatkan kepentingan klien diatas kepentingan pribadi anda.

6) Jangan bedakan pelayanan klien atas dasar SARA dan status sosialnya.

c. Keterampilan Dasar Pembimbing Kemasyarakatan Pelaksanaan bimbingan tidak semudah yang diperkirakan sehingga pembimbing kemasyarakatan harus mempunyai keterampilan sebagai berikut :

1) Keterampilan membangun relasi antar manusia.

2) Keterampilan menganalisa situasi pribadi klien baik individu maupun kelompok.

3) Keterampilan berpartisipasi dengan individu dan kelompok.

4) Keterampilan mengatasi perasaan orang lain.

5) Kecakapan menyusun rencana/program layanan.

6) Kecakapan melaksanakan program dengan menggunakan sumber atau sistem pelayanan yang ada disekitarnya untuk dimanfaatkan bagi kepentingan kliennya.

7) Kecakapan melakukan evaluasi.

Adapun Bimbingan pokok yang dilaksanakan di Bapas Kelas II Pekanbaru yang harus dilaksanakan yaitu:

a. Bimbingan Kepribadian Dalam pelaksanaannya diharapkan klien memahami diri dan dapat mengambil keputusan positif karena klien sudah dapat menguasai diri, serta sadar akan perbuatannya dan tidak akan mengulanginya lagi, namun bimbingan yang dilakukan hanya nasehat agama seperti mengajak sholat, mengajak untuk berbuat baik itu saja. Padahal seharusnya apabila Pembimbing Kemasyarakatan kurang mampu maka dapat bekerjasama dengan tokoh agama, b. Bimbingan

Kemandirian, kemandirian adalah perilaku mampu berinisiatif, mampu mengatasi hambatan atau masalah, mempunyai rasa percaya diri dan dapat melakukan sesuatu tanpa bantuan orang lain, hasrat untuk mengerjakan segala sesuatu bagi diri sendiri (Jauhari, 1997). Jadi bimbingan yang dilakukan oleh Pembimbing Kemasyarakatan meliputi bimbingan kerja atau pengembangan keterampilan, dimana dalam Bapas Kelas II Pekanbaru memberikan bimbingan kemandirian ini dalam bentuk pengajaran pembuatan suatu benda dan sosialisasi tentang berdagang, c. Bimbingan Konseling Menurut Abu Ahmadi (1991:1) bahwa bimbingan adalah sebuah bantuan yang diberikan terhadap individu (Klien) agar mengetahui potensi diri yang dimiliki dan dikembangkan secara optimal dengan jalan memahami diri sendiri, lingkungan dan mengatasi setiap hambatan guna menentukan rencana yang lebik baik untuk kedepannya. 
Diperlukan seorang psikolog dalam memberikan setiap arahan terhadap klien dan mengerti setiap permasalahan yang mereka alami dan memberikan solusi terbaik tentang apa yang baik untuk mereka lakukan agar tidak kembali mengulangi kejahatan yang sama ataupun tindak pidana lainnya.

Adapun hambatan yang dialami oleh Pembimbing Kemasyarakatan dalam melaksanakan bimbingan terhadap klien yaitu:

1. Jauhnya jarak yang ditempuh oleh klien dalam mengikuti program bimbingan yang akan diberikan

2. Kurangnya sarana dan prasarana dalam pelaksanaan bimbingan

3. Dan masih kurangnya kesadaran diri klien untuk ingin berubah menjadi lebih baik lagi.

\section{Kesimpulan}

Berdasarkan hasil penelitian dan pembahasan yang telah dikemukakan pada bab-bab sebelumnya mengenai optimalisasi peran pembimbing kemasyarakatan dalam bimbingan klien dewasa di Bapas Kelas II Pekanbaru, maka penulis dapat menarik beberapa kesimpulan sebagai berikut :

1.Pembimbing kemasyarakatan merupakan petugas teknis yang memberikan bimbingan kepada klien pemasyarakatan. Pembimbing kemasyarakatan mempunyai tanggung jawab yang besar terhadap pelaksanaan bimbingan dan pencegahan resiko residivis, dan tujuan Re-Integrasi dapat berjalan sesuai dengan yang diharapkan, maka dari itu Pembimbing Kemasyarakatan mempunyai peranan sebagai berikut :

\begin{tabular}{lr} 
a.Broker yaitu & Pembimbing \\
Kemasyarakatan & \multicolumn{2}{r}{ membantu } \\
menyediakan pelayanan sosial \\
kepada klien.
\end{tabular}
b.Mediator yaitu Pembimbing Kemasyarakatan dapat menghubungkan klien dengan berbagai sumber pelayanan sosial yang ada dalam masyarakat.
c.Public educator yaitu Pembimbing Kemasyarakatan dapat memberikan dan menyebarkan informasi mengenai masalah dan pelayanan- pelayanan sosial yang tersedia.

d. Advocate yaitu Pembimbing Kemasyarakatan dituntut untuk membela klien dalam memperjuangkan hak-haknya memperoleh pelayanan atau menjadi "penyambung lidah" klien agar lembaga lebih responsive memenuhi kebutuhan klien.

e.Behavior Specialist adalah Pembimbing Kemasyarakatan harus menjadi ahli yang dapat melakukan berbagai strategi dan teknik pengubahan perilaku.

f. Konsultan yaitu Pembimbing Kemasyarakatan harus memberi nasehat dan saran profesional kepada klien mengenai berbagai cara pemenuhan kebutuhan dan pemecahan masalah.

g. Konselor yaitu Pembimbing Kemasyarakatan dapat memberikan pelayanan penyelesaian masalah.

Dari peranan Pembimbing kemasyarakatan tersebut Pembimbing Kemasyarakatan dituntut mempunyai pengetahuan dan keterampilan teknis dalam bidang pekerjaan sosial, khususnya dalam menerapkan metode dan teknik bimbingann terhadap klien dewasa.

2. Faktor faktor yang menjadi kendala dalam memberikan program bimbingan terhadap klien :

1.Jauhnya jarak yang ditempuh oleh klien dalam mengikuti program bimbingan yang akan diberikan 
2.Kurangnya sarana dan prasarana dalam pelaksanaan bimbingan

3. Dan masih kurangnya kesadaran diri klien untuk ingin berubah menjadi lebih baik lagi.

Saran

Dalam penelitian ini peneliti memberikan sedikit rekomendasi dalam pengoptimalan peran Pembimbing Kemasyarakatan dalam pencegahan resiko residivis yaitu:

1) Perlu ditingkatkan kualitas pembimbing kemasyarakatan mengingat pentingnya peranan yang dijalankan dalam memberikan bimbingan terhadap klien dewasa.

2) Untuk menjamin kualitas pembimbingan kemasyarakatan hendaknya persyaratan untuk menjadi pembimbing kemasyarakatan perlu ditinjau kembali persyaratan yang sesuai dengan jurusan dan bidang tugasnya.

3) Pemberian kesempatan kepada para pembimbing kemasyakatan untuk meningkatkan kualitas sebagai pekerja sosial dengan profesional dengan jalan memberikan kesempatan untuk melanjutkan pendidikan ke jenjang yang lebih tinggi.

\section{Buku}

\section{Daftar Pustaka}

Bungin, B. (2006). Metode Penelitian Kualitatif. Rajawali Pub.

Sujatno, A. (2004). Sistem pemasyarakatan Indonesia: membangun manusia mandiri. Jakarta: Direktorat Jenderal Pemasyarakatan, Departemen Kehakiman dan HAM.

Jauhari, I. (1997). Peranan pembimbing kemasyarakatan dalam pembinaan narapidana di luar lembaga pemasyarakatan: suatu penelitian pada Balai
Bimbingan Kemasyarakatan dan Pengentasan Anak (Bispa) Banda Aceh: laporan hasil penelitian. Darussalam, Banda Aceh: Universitas Syiah Kuala

\section{Jurnal}

Bungin, B. (2006). Metode Penelitian Kualitatif. Rajawali Pub.

Sujatno, A. (2004). Sistem pemasyarakatan Indonesia: membangun manusia mandiri. Jakarta: Direktorat Jenderal Pemasyarakatan, Departemen Kehakiman dan HAM.

Jauhari, I. (1997). Peranan pembimbing kemasyarakatan dalam pembinaan narapidana di luar lembaga pemasyarakatan: suatu penelitian pada Balai Bimbingan Kemasyarakatan dan Pengentasan Anak (Bispa) Banda Aceh: laporan hasil penelitian. Darussalam, Banda Aceh: Universitas Syiah Kuala.

\section{$\underline{\text { Jurnal }}$}

Patuju, L., \& Afamery, S. S. (2019).

Residivis Dalam Perspektif

Sosiologi Hukum. Jurnal

Hukum Volkgeist, 104-114.

Peraturan Pemerintah Nomor 31 Tahun $1999 \quad$ Tentang

Pembinaan dan

Pembimbingan Warga Binaan

Pemasyarakaan . (n.d.).

Peraturan Pemerintah Nomor 99 Tahun 2012 tentang Syarat dan Pelaksanaan Hak Warga Binaan Pemasyarakatan . (n.d.).

Pratiwi, S. A., \& Lemes, I. N. (2019). Pelaksanaan Pembinaan Narapidana Sebagai Upaya Mengatasi Timbulnya Residivis Di Lembaga 
Pemasyarakatan Kelas Iib Singaraja. Kertha Widya.

Rahmat, D. (2018). Pembinaan Narapidana Dengan Sistem Pemasyarakatan. Pranata Hukum, 181-186.

Santoso Darwis, M. (2017). PERAN PEMBIMBING KEMASYARAKATAN

DALAM PENANGANAN ANAK BERKONFLIK DENGAN HUKUM OLEH BALAI PEMASYARAKATAN.

Share : Social Work Journal, 61.

Undang-Undang Nomor 11 Tahun 2012 tentang Sistem Peradilan Pidana Anak . (n.d.).

Undang-Undang Nomor 12 Tahun 1995 tentang Pemasyarakatan . (n.d.).

Undang-Undang Nomor 39 Tahun 1999 tentang Hak Asasi Manusia. (n.d.). 